\title{
Pengembangan Game Based Learning Materi Grammar \\ Bahasa Inggris Dalam Kurikulum 2013 Kelas X SMA Negeri 3 Sragen
}

\author{
Budi Setiawan ${ }^{7}$, Nunuk Suryani ${ }^{8}$, Suharno ${ }^{9}$ \\ setyawanbudy44@gmail
}

\begin{abstract}
This Research is aimed to test the effectiveness of game-based learning multimedia in order to improve student learning outcomes on English subject with the tpic of grammar in the classroom. The research development of multimedia game-based learning using the procedure of Raiser and Demsey consisting of 8 stages namely:1) Analysis, 2) Design 3) Development. 4) Implement, 5) Evaluate. The trial of product development tested had passed several processes covering; the review from media's expert which includes software changes and visual communication, the review from content's expert covers material and instructional design, students' responses towards products' usage and attractiveness, small group and big group test trial. The results of the feasibility test of a team of experts covering media expert results obtained 4,7 categorized as very good and content experts 4,7 which is at a range of very good category. After the product is revised based on the experts' input, it is tried and tested to the trial class students at a small group scope with the result of 4,6 for their responses to the product and improving score from the pretest which is 52,11 to be 67,55. Next, at the large scale trial at the experiment class to see the effectiveness of the game based learning multimedia shows that there is a difference on the student's learning result. On the pretest of control class, the score is 56.00 and the final score in the posttest of the same class is 64,43.if it is compared with the pretest score from the experiment class, the score is lower which is 55.90, but it improves rapidly on the posttest after being treated with multimedia game based learning and come to score 71.65 with the significant value 0.05. thus, it can be said that the result of the development of multimedia game-based learning is effective to improve students learning outcomes.
\end{abstract}

Keywords: Multimedia, game-based learning, grammar, learning outcomes

\footnotetext{
${ }^{7}$ Mahasiswa Magister Teknologi Pendidikan Universitas Sebelas Maret Surakarta

8 Dosen Universitas Sebelas Maret Surakarta

${ }^{9}$ Dosen Universitas Sebelas Maret Surakarta
} 


\section{PENDAHULUAN}

$\mathrm{P}$

ergantian kurikulum akan berdampak logis pada penyesuaian dan perubahan beragam standar yang ada dalam suatu kurikulum yang telah dirancang dan ditetapkan, termasuk didalamnya standar kompetensi khususnya perubahan kurikulum KTSP menjadi K-13. Ada efek langsung dan tidak langsung sebagai dampak pengiring sebagai akibat kebijakan tersebut. Berpijak pada fungsinya, maka tujuan pengajaran Mata Pelajaran Bahasa Inggris mencakup: (1) Mengembangkan kemampuan berkomunikasi dalam bahasa tersebut baik lisan maupun tulis. Kemampuan tersebut meliputi mendengarkan (listening), berbicara (speaking), membaca (reading), dan menulis (writing); (2) Menumbuhkan kesadaran akan hakikat dan pentingya bahasa Inggris sebagai salah satu bahasa asing untuk menjadi alat utama belajar; (3) mengembangkan pemahaman keterkaitan antara bahasa dan budaya serta memperluas cakrawala budaya. Dengan demikian siswa memiliki wawasan lintas budaya dan melibatkan diri dalam keragaman budaya.

Tak terkecuali dengan mata pelajaran bahasa Inggris. Berdasarkan sebaran isi yang mengacu pada silabus, nampak adanya perbedaan yakni dimasukkannya ketrampilan grammar atau tata bahasa dalam mata pelajaran bahasa inggris kelas X SMA. Dalam bahasa inggris, grammar memiliki pola yang bermacam- macam berdasarkan konteks waktunya. Hal ini akan menimbulkan kesulitan bagi siswa bila porsi belajar peserta didik tidak difasilitasi dengan besarnya porsi oleh guru untuk memahamankan konsep dasar melalui teacher centred. Disisi lain, kurikulum 2013 menuntut siswa menjadi lebih aktif dalam segenap aspek dengan porsi guru lebih sedikit dalam proses kegiatan belajar mengajar. Akibat jangka pendek yang bisa terlihat secara langsung adalah kebingungan dan ketidakpahaman akan konsep dasar pola kalimat dalam bahasa inggris tersebut. Hal ini bisa berimplikasi besar dalam capaian ranah kognitif atau akademik peserta didik tersebut.

Peran guru dalam memilih dan menentukan materi pembelajaran atau bahan ajar menjadi sangat penting dalam menjembatani permasalahan peserta didik dalam kegiatan pembelajaran. Sudah hampir menjadi budaya turun menurun bagi banyak kalangan pendidik sampai saat sekarang ini dalam hal ini guru khususnya masih memakai metode atau teknik yang masih konvensional dalam kegiatan belajar mengajar. Pemanfaatan bahan ajar dan media pembelajaran pun tak luput dari kurangnya inovasi dari hampir sebagian besar para pendidik.

Pada era generasi milenia pada saat sekarang ini dan menjadikan generasi global citizen maka tidak bisa dipungkiri bahwa komputerisasi menjalar hampir disegala lini kehidupan manusia. Bahkan dunia pendidikan pun tak luput dari invasi computer atau yang biasa sering kita sebut dengan dunia digital ini. Semakin berkembang bentuk pembelajaran yang memanfaatkan computer sebagai sumber belajar selain buku. Menurut Simonson \& Thomson (1994), Pembelajaran Berbantuan Komputer efektif dalam memperbaiki penguasaan siswa dalam semua jenjang pendidikan, sangat efektif dalam memperbaiki penguasaan siswa pada tingkat sekolah dasar yang berlanjut pada tingkat menengah sampai perguruan tinggi dan dapat menghemat waktu untuk pembelajaran.

Pernyataan tersebut dikuatkan oleh Miarso (2005) bahwa pembelajaran yang dikembangkan dengan atau berbantuan komputer ternyata mampu meningkatkan motivasi dan daya serap siswa terhadap materi pelajaran. Hal tersebut dikarenakan metode pembelajaran berbantuan komputer mampu menumbuhkan motivasi bagi siswa untuk lebih menekuni materi yang disajikan, menambah 
realisme dan merangsang untuk mengadakan latihan-latihan kerja, dan dapat merangsang siswa dalam merespon materi pelajaran untuk meningkatkan prestasi belajarnya.

Penggunaan media yang masih konvensional menjadi hal krusial yang perlu dibenahi dikarenakan hanya bertumpu pada satu media saja yakni buku. Perlu adanya inovasi dalam menyajikan materi ajar dalam format atau bentuk media lain yang bersifat interaktif yang mampu menarik antusiasme dan keaktifan siswa, yang salah satunya adalah melalui multimedia pembelajaran interaktif berbasis komputer.

Traditionally, grammar has been concerned almost exclusively with analysis at the level of the sentence. Thus grammar is a description of the rules that govern a language's sentence are formed (Thornburry, 2002: 1). Bisa dikatakan bahwa grammar berkaitan dengan tingkatan kalimat dan gambaraan tentang aturan yang mengatur dibentuknya sebuah kalimat dalam bahasa. Disini focus lebih pada kalimat dan bagaimana membentuknya. Sedangkan menurut Ur (2009) menyatakan bahwa in which grammar in general is sometimes defined as the way words are put together to make correct sentences. Pendapat ini memiliki kesamaan yang diungkapkan sebelumnya oleh Thornburry yang mana berkaitan dengan peraturan tentang bagaimana kalimat itu disusun secara lengkap.

Definisi terakhir oleh Harmer (2006) menerangkan bahwa communicative competence involves knowing how to use the grammar and vocabulary of the language to achieve communicative goals, and knowing how to do this in a socially appropriate way. Grammar berkatan dengan pengetahuan dan ketrampilan: bagaimana untuk mengenali contoh grammar ketika diucapkan, bagaimana cara mengidentifikasinya dalam bentuk tulisan, bagaimana membuatnya baik dalam bentuk lisan dan tulisan, bagaimana memahami maknanya berdasarkan konteks, dan menghasilkan kalimat bermakna dalam penggunannya.

Grammar adalah salah satu komponen bahasa selain pelafalan, pengejaan dan kosakata serta menjadi sangatlah esensial sebagai alat atau cara untuk berkomunikasi. Suyanto (2007) mengungkapkan bahwa grammar terdiri dari pola dan aturan bahasa yang seharusnya dipelajari jika kita ingin berbicara dalam bahasa inggris secara tepat. Richards (2008) menekankan bahwa structure is still important to be taught in teaching English, he furthermore says that now teaching structure has controversial issues in teaching English, but in recent years, grammar teaching has regained its rightful place in language curriculum. Mengajarkan grammar masih dirasa penting dalam kegiatan belajar mengajar yang menjadikan sarana penting dalam berkomunikasi. Bahasa akan menjadi berterima jika memiliki grammar yang tepat.

Smaldino, Lowther, \& Russell (2007) menyatakan bahwa media adalah bentuk jamak dari perantara (medium), merupakan sarana komunikasi. Istilah ini merujuk pada apa saja yang dapat membawa informasi dari sumber ke penerima. Sedangakan menurut Pudjiastuti (1999) media adalah segala sesuatu yang dapat menyalurkan pesan dari pengirim ke penerima pesan sehingga dapat merangsang pikiran, perasaan, perhatian, dan minat siswa sedemikian rupa sehingga terjadi proses belajar.

Menurut Hackbarth (1996) bahwa multimedia diartikan sebagai suatu penggunaan gabungan beberapa media dalam menyampaikan informasi yang berupa teks, grafis atau animasi grafis, movie, video dan audio. Multimedia yang berbasis komputer meliputi hypermedia dan hypertext. Hypermedia yaitu suatu penggunaan format presentasi multimedia yang meliputi teks, grafis diam atau animasi, 
bentuk movie dan audio. Hypertext yaitu bentuk teks, diagram statis, gambar dan table yang ditayangkan dan disusun secara tidak linear (urut atau segaris).

Roblyer (2003) menyatakan multimedia atau media kombinasi merupakan media yang terdiri dari gambar diam, suara, video gerak, animasi dan yang teks digabungkan dalam suatu produk yang bertujuan untuk memberikan informasi. Rob Philip (1997) menyatakan multimedia adalah gabungan dari teks, gambar, suara, animasi dan video; beberapa komponen tersebut atau seluruh komponen tersebut dimasukkan ke dalam program yang koheren. Sedangkan Munir (2008) menyatakan bahwa sajian multimedia dapat diartikan sebagai teknologi yang mengoptimalkan peran komputer sebagai media yang menampilakan teks, suara, grafik, video, animasi dalam sebuah tampilan yang terintegrasi dan interaktif.

Komputer menjadi sarana utama untuk penyajian program multimedia. Komponen dalam komputer mampu menampilkan gabungan audio maupun visual secara integratif dan apik dalam satu program. Kesan interaksi yang terbangunpun menjadi sangat hidup dikarenakan diberikannya kesempatan oleh para pengguna untuk terlibat dalam kegiatan tersebut.

Game merupakan sebuah kegiatan yang menghibur dan menimbulkan ketertarikan, cenderung pada memberikan tantangan, dan juga sebuah kegiatan yang mana pebelajar bermain dan berinteraksi satu sama lain. Menurut Wright et al (2006) menyatakan bahwa competition against others is not essential ingredient for games, but challenge is. Dalam memilih dan menggambarkan permainan, sebaiknya sebisa mungkin meminimalisir kompetisi, adanya pemenang dan pihak yang kalah, dan memaksimalkan tantangan, dimana setiap orang merasa terinspirasi untuk mulai bermain dan melakukan yang terbaik.

Secara umum video game adalah permainan jenis apapun yang dimainkan dengan perangkat computer dan berupa tampilan video. Media yang digunakan bisa melalui computer, telepon seluler, atau game console. Pengertian tersebut adalah sebuah konsep umum yang mencerminkan pemahaman kita semua secara umum dari istilah "digital game" yang mana tidak menyebutkan keseluruhan komponen yang cukup kompleks yang ada didalamnya. Menurut ProActive: Fostering teachers' creativity through Game-Based Learning (2009), berikut ini adalah beberapa karakteristik atau ciri- ciri video game yang berkualitas baik, digemari oleh khalayak umum dan menarik, antara lain; Conflict, Goal and Rules, Short Feedback Cycles, Immersion and Engagement, Challenge, Adaptability, Replayability, Reward System, Competition. digital games tersebut mengkondisikan pemainnya dalam sebuah dunia yang tanpa batas untuk menjelajah tanpa adanya intervensi dari instruktur, video games adalah sebuah media yang ideal untuk memajukan pembelajaran nyata dan proses "learning by doing" yang mampu mengubah peserta didik pemimpin atas diri mereka sendiri dalam pengalaman belajarnya. Digital games mampu memberikan pengalaman belajar yang bermakna dengan merangsang interaksi yang seorang professional dalam bidang ini temukan dalam dunia nyata, dimana mereka hadapi secara langsung terkait permasalahan yang ada.

\section{METODE PENELITIAN}

Penelitian dilakukan di SMA N 3 Sragen. Penelitian ini dilaksanakan pada mata pelajaran Bahasa Inggris di kelas X. Waktu penelitian adalah pada semester II tahun ajaran 2016/2017 dengan melibatkan sejumlah empat kelas yang berbeda, yakni kelas uji coba produk, kelas uji coba soal, kelas 
eksperimen dan kelas kontrol. Penelitian ini diklasifikasikan sebagai penelitian pengembangan (Research and Development).

Prosedur penelitian pengembangan terdiri atas dua tahap yaitu mengembangkan produk model dan menguji kualitas dan atau efektifitas produk yang dihasilkan (Sukardjo \& Sari, 2009). Dalam penelitian pengembangan dikenal salah satu model pengembangan yaitu model ADDIE. Model pengembangan ADDIE merupakan model desain pembelajaran yang berlandasan pada pendekatan sistem yang efektif dan efisien serta prosesnya yang bersifat interaktif yakni hasil evaluasi setiap fase dapat membawa pengembangan pembelajaran ke fase selanjutnya. Hasil akhir dari suatu fase merupakan produk awal bagi fase berikutnya. Model ini terdiri atas 5 fase atau tahap utama yaitu 1) Analyze (Analisis), 2) Design (Desain), 3) Develop (Pengembangan), 4) Implement (Implementasi), 5) Evaluate (Evaluasi).

\section{HASIL DAN PEMBAHASAN}

\section{Multimedia Game Based Learning}

Pengembangan produk yang akan digunakan sebagai multimedia pembelajaran ini telah melalui beberapa tahap yang meliputi produksi, validasi ahli media, validasi ahli materi dan uji coba produk. Berikut adalah tampilan model final multimedia tersebut.

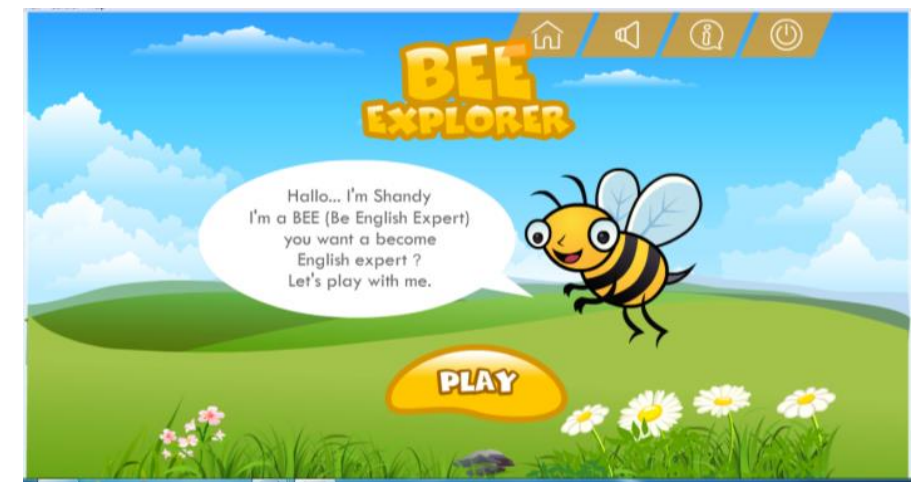

Gambar 1. Tampilan Games

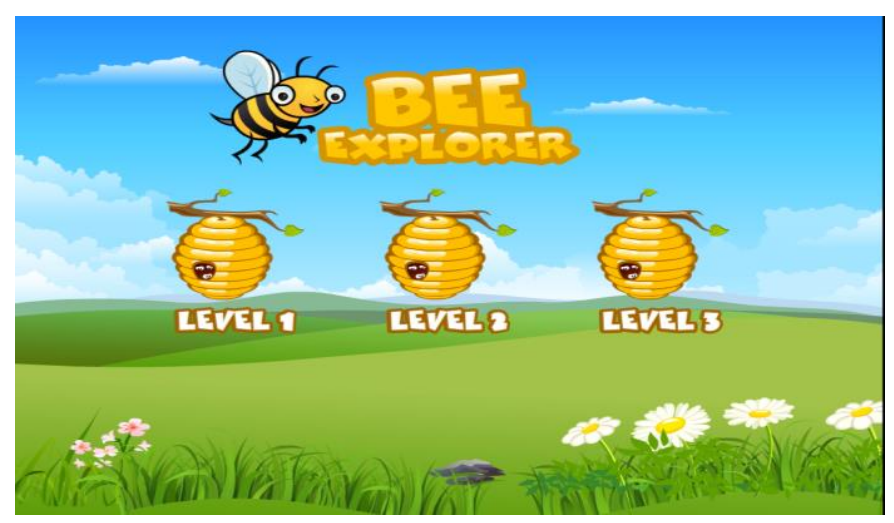

Gambar 2. Level Games 
Setelah melakukan uji prasyarat analisis, tahap selanjutnya adalah menguji keefektifan produk tersebut melalui uji t-test. Percobaan dilakukan pada 64 siswa SMA dengan rincian; 32 siswa menggunakan multimedia game-based learning pada kelas eksperimen dan 32 siswa menggunakan buku siswa pada kelas kontrol. Diketahui bahwa nilai signifikansi uji-t adalah 0,000. Nilai signifikansi tersebut kurang dari 0,05 yang berarti nahwa $\mathrm{H} 1$ diterima. Serta nilai thitung adalah sebesar $4.294>_{\text {table }}$ yaitu sebesar 1,669. Hal ini menunjukkan terdapat perbedaan yang signifikan rata-rata hasil belajar siswa antara kelas eksperimen dan kelas kontrol. Hal tersebut menunjukkan bahwa hasil belajar siswa kelas eksperimen lebih baik daripada kelas kontrol.

Tabel 1. Rata-rata Nilai Pretest dan Posttest

\begin{tabular}{lll}
\hline Nilai & Kelas Eksperimen & Kelas Kontrol \\
\hline Pretest & 55.90 & 56 \\
\hline Posttest & 71.65 & 64.43
\end{tabular}

Hasil data penelitian yang telah dijelaskan diatas memiliki korelasi atau hubungan yang positif terhadap teori dan atau hasil- hasil penelitian terdahulu yang dikemukakan sebelumnya terkait penggunaan media yang mampu meningkatkan hasil atau prestasi belajar siswa. Produk multimedia yang digunakan bisa disimpulkan efektif dalam mendukung dan memfasilitasi siswa dalam capaian akademik baik dalam ranah kognitif, afektif dan psikomotornya. Pembelajaran dengan multimedia yang memadukan audio dan visual dalam hal ini spesifik pada games atau permainan mampu merangsang keaktifan, minat dan perhatian siswa terhadap pokok bahasan materi tertentu pada sebuah kegiatan pembelajaran. Hal ini sesuai dengan pernyataan dari Pudjiastuti (1999) media adalah segala sesuatu yang dapat menyalurkan pesan dari pengirim ke penerima pesan sehingga dapat merangsang pikiran, perasaan, perhatian, dan minat siswa sedemikian rupa sehingga terjadi proses belajar. Diperkuat juga dengan teori menurut (Arsyad, 2013) yang mengemukakan bahwa media pembelajaran dapat memperjelas penyajian pesan dan informasi sehingga dapat memperlancar serta meningkatkan proses dan hasil belajar. Pendapat yang serupa yang mendukung pernyataan diatas juga dikemukakan oleh Rudi dkk (2009) yang menjelaskan bahwa multimedia memiliki beberapa karakteristik yang secara umum mampu memberikan sarana belajar yang padu bagi siswa diantaranya; self instructional (belajar mandiri), self contained (keterpaduan kompetensi dan sub kompetensi), stand alone (mampu berdiri sendiri), dan user friendly (mudah pengoperasiannya). Hal ini sesuai dan diperkuat oleh teori menurut Vaughan (2008) yang mengemukakan bahwa penggunaan multimedia mampu memberikan perubahan sikap siswa terhadap kegiatan belajar menagajar dari semula passive- learner menjadi active- learner dengan adanya pengalaman belajar didalamnya. Peran guru juga lebih cenderung sebagai pemandu atau fasilitator salam pembelajaran dan menjadikan siswa itu sendiri menjadi pusat utama dalam kegiatan pembelajaran (student centered).

Beberapa penelitian yang telah dilakukan sebelumnya juga mendukung hasil penelitian yang telah dipaparkan diatas. Hasil Penelitian yang dilakukan oleh Chen, Wang, \& Lin (2015) tentang The Comparison of Solitary and Collaborative Modes of Game-based Learning on Students' Science Learning and Motivation menunjukkan bahwa permainan baik secara individu maupun kelompok tidak menunjukkan adanya perbedaan dalam capaian hasil belajar. Hal ini terlihat dari Games baik secara mandiri maupun bersama- sama mampu memberikan peningkatan yang signifikan dari pretest ke posttest. Hal ini menunjukkan bahwa pengalaman permainan meningkatkan keseluruhan pembelajaran 
mereka. Hasil penelitian juga menunjukkan bahwa permainan dapat mendorong eksplorasi ilmu pengetahuan secara implisit.

\section{KESIMPULAN}

Proses pembelajaran cenderung lebih berkutat pada ceramah atau teacher centred. Sarana penunjang hanya berupa bahan ajar dalam bentuk buku siswa yang diperoleh dari sekolah sebagai buku pegangan dengan materi yang terkesan ringkas dan lebih pada garis besar pada tiap pokok bahasan. Sesekali menggunakan media gambar, sehingga siswa kurang tertarik. Siswa membutuhkan media tambahan atau media penunjang untuk membantu dalam mempelajari dan memahami materi pelajaran yang yang disampaikan guru di sekolah. Porsi guru lebih diposisikan sebagai pusat dari segala sumber informasi kepada siswa. Disisi lain, sekolah sudah mengadopsi dan menerapkan kurikulum 2013 yang mana lebih mengedepankan pendekatan berbasis scientific dan proses pembelajaran lebih bertumpu pada siswa atau yang biasa disebut dengan student centred. Dengan diterapkannya multimedia game-based learning sebagai media pembelajaran berkorelasi positif terhadap capaian hasil dan sikap belajar siswa. Hal ini dapat dilihat dari peningkatan prestasi belajar siswa pada saat pretest dan posttest serta motivasi siswa terhadap pelajaran.

\section{SARAN- SARAN}

Berdasarkan hasil penelitian dan pengembangan multimedia pembelajaran berbasis game-based learning kelas X di SMA Negeri 3 Sragen, maka diajukan saran sebagai berikut:

\section{Kepada Guru}

Penelitian dan pengembangan multimedia pembelajaran berbasis game-based learning pada mata pelajaran bahasa inggris pokok bahasan grammar past simple semester genap telah dinyatakan layak dan dapat meningkatkan hasil belajar siswa, akan tetapi ada beberapa hal yang peneliti sarankan terhadap pengembangan produk multimedia ini, diantaranya:

a. Hendaknya guru membaca terlebih dahulu petunjuk teknis penggunaan dari multimedia yang akan digunakan sebelum mengoperasikannya.

b. Guru melakukan cek dari segi aplikasi multimedia pembelajaran dan peralatan penunjang lain sebelum secara langsung mengoperasikannya di kelas ataupun dalam laboratorium computer atau bahasa.

c. Guru dapat memodifikasi multimedia dengan menambah ilustrasi gambar pendukung lain yang mampu semakin menunjang pemahaman siswa terhadap materi pelajaran yang disajikan variasi soal serta tingkat kesulitan dari level permainan yang ada didalamnya.

\section{Kepada Sekolah}

a. Bagi sekolah perlu memberikan pelatihan bagi guru untuk lebih meningkatkan kompetensinya terkait penguasaan IT dan program perangkat lunak lain yang mampu menunjang guru dalam memfasilitasi siswa dalam kegiatan pembelajaran sehingga tercipta beragam media pembelajaran yang lebih beragam dan atraktif. 
b. Produk multimedia game based learning ini bisa digunakan dalam perangkat computer duduk dan jinjing dengan hanya menduplikasi file dan langsung bisa dioperasikan secara cepat dan mudah. Selain itu juga file bisa diperbanyak dalam bentuk CD.

3. Kepada Siswa

a. Bagi siswa yang memilki perangkat computer, produk multimedia berbasis game based learning ini bisa digunakan sebagai media belajar mandiri karena memilki beberapa keunggulan yang mana bisa diputar, dipilih dan dipelajari kembali dari beberapa materi tertentu yang dirasa masih sulit untuk dipahami.

\section{DAFTAR PUSTAKA}

Arsyad, A. (2013). Media Pembelajaran. Jakarta: PT Raja Grafindo Persada.

Brown, (2001). Teaching by Principle: An Imperative Approach to Language Pedagogy, $2^{\text {nd }}$ Edition. New York: Addison Wesly Longman, Inc.

Chen, C.-H., Wang, K.-C., \& Lin, Y.-H. (2015). The Comparison of Solitary and Collaborative Modes of Game-based Learning on Students' Science Learning and Motivation. Educational Technology \& Society, 18 (2), pp. 237-248. http://ebscho.com diakses pada tanggal 13 September 2016.

Hacbarth, S. (1996). The educational technology handbook. New Jersey: Educational Technology Publications Inc.

Harmer, J. (2006). How to Teach Grammar. London. Longman

Heinich, Molenda, Russell, and Smaldino. (1996) Instructional Media and Technologies for Learning. Prentice-Hall, Inc. New Jersey: Upper Saddle River.

Munir. (2013). Multimedia Konsep dan Aplikasi dalam Pendidikan. Bandung: Alfabeta.

Raiser, R. A \& Dempsey, J. V. (2007). Trends and Issues in Instructional Design and Technology. Secon Edition. New Jersey: Pearson Merril Prentice Hall.

Richards, J.C. (2008). Methodology in Language Teaching. An Anthology of Current Practice. New York: Cambridge University Press.

Roblyer, M.D. (2003) Integrating educational technology into teaching (3rd ed) New Jersey. Merril Prentice Hall.

Smaldino, S. E. dkk. (2011). Instructional technology \& media for learning. Jakarta: Kencana.

Poedjiastoeti, S. (1999). Media Pembelajaran. Surabaya: Unipres Unesa.

Sukardjo \& Sari, L. P. (2009). Metodologi Penelitian Pendidikan Kimia. Yogyakarta: FMIPA UNY.

Vaughan, T. (2008). Multimedia: Making It Work. New York: Mc Graw Hill.

Thornburry. S. (1999). How to Teach Grammar. England: Pearson Education L Limited (Longman).

Ur, P. (2009). A Course in Language Teaching Practice and Theory. Cambridge University Press. 
Wright, A., Betteridge, D., \& Buckby. M. (2006) Games For Language Learning. Third Edition. Cambridge University Press. (2009) ProActive: Fostering teachers' creativity through Game-Based Learning. 